\title{
Economic Valuation of Conservation of Inholdings in Protected Areas for the Institution of Payments for Ecosystem Services
}

\author{
Chi-Ok Oh ${ }^{1}$, Sangkwon Lee ${ }^{2}$ and Hyun No Kim ${ }^{3, * \mathbb{C}}$ \\ 1 Graduate School of Culture, Chonnam National University, Gwangju 61186, Korea; chiokoh@gmail.com \\ 2 College of Arts, Sciences, Business and Education, Winston-Salem University, Winston-Salem, NC 27110, \\ USA; lees@wssu.edu \\ 3 Sustainable Strategy Research Group, Korea Environment Institute, Sejong 30147, Korea \\ * Correspondence: hnkim@kei.re.kr; Tel.: +82-44-415-7985
}

Received: 5 November 2019; Accepted: 6 December 2019; Published: 9 December 2019

\begin{abstract}
Ecosystem services, as public goods, are often undersupplied because private markets do not fully take into account the social cost of production. To alleviate the concern about this imbalance situation, payments for ecosystem services (PES) have emerged as a preferable alternative. While temples in Korea have owned a considerable part of the national parks, a PES approach can be used as a viable option to alleviate the conflicts among visitors, non-visitors, and temples. The purpose of this paper is to assess the economic values of ecosystem services provided by temple forests as a compensation mechanism. Using a contingent valuation method, an online survey was conducted with 1000 respondents. Study results showed that the economic benefits of the conservation of temple forests were estimated to be substantial, ranging from $\$ 5980$ (US \$5.42) to \$7709 (\$7.08) per household per year. The results also confirmed the effects of social factors such as individuals' trust in the government's environmental policies and importance on the conservation of temples' cultural and religious values on the willingness to pay. With a growing interest in securing ecosystem services through a PES approach, estimating economic benefits of the conservation of inholdings in public protected areas will be a valuable piece of information as an important policy decision-making tool.
\end{abstract}

Keywords: economic valuation; contingent valuation method; payments for ecosystem services; national parks; willingness to pay

\section{Introduction}

While the existence and livelihoods of humans depend on ecosystems and the functions of ecosystem services [1], ecosystem services have been continually lost or reduced. The Millennium Ecosystem Assessment [2] reported that humans can be blamed for a reduction of $60 \%$ of ecosystem services due to their fast-growing needs of agriculture, forestry, fisheries, industries, and urban dwellings over the past 50 years. The rate of deforestation is also alarming. The World Bank [3] indicated that 1.3 million $\mathrm{km}^{2}$ of forests have disappeared between 1990 and 2015, which are equivalent to an area larger than the size of South Africa.

Many ecosystem services (e.g., maintaining biodiversity, enjoying views over a landscape areas) are considered to be public goods, meaning that one person cannot prevent others from using the resources (i.e., non-excludable) and the consumption of one person does not reduce the consumption accessibility of others (i.e., non-rival) [4]. Furthermore, certain ecosystem services (e.g., fishery stocks, timber production in forests) belong to common property resources (or common goods), based on 
the characteristics that the consumption of the resources by one person precludes other people's consumption (i.e., rival instead of being non-rival). A primary concern of common property resources is overuse and possibly the irreversible depletion of the resources.

The chronic degradation of ecosystems partly results from the fact that many ecosystem services, as common property resources, are undersupplied because private markets do not fully internalize environmental externalities. In other words, when a consequential part of ecosystem services is produced as a form of by-product or an externality of primary ecosystem functions, the society has a tendency to underprovide sufficient quantities of common property resources $[5,6]$. This is classical of market failures, which results from a gap between private and social benefits.

One effective means that can help remedy this imbalance situation is to provide incentives (i.e., subsidies) $[7,8]$. This kind of institution can embrace the value of ecosystem services by rewarding resource owners/users, which can help suite resource use decisions with the social interest in the management of natural resources $[9,10]$. Payments for ecosystem services (PES) have emerged as a preferable alternative recently. A PES approach, as an incentive mechanism, is innovative because it adopts a beneficiary-pays principle rather than the relatively older proposition of polluter pays $[7,10]$.

One area that the PES can be effectively used is ecosystem services provided by private lands in protected areas such as national parks. Most people think that national parks are designated as 'public protected areas' for the purpose of conserving natural and cultural resources and enhancing an individual's quality of life through park visitation. This premise is not completely correct because people can find private lands spotted throughout national parks as inholdings. While there are various explanations for the occurrence of inholdings in national parks, a primary reason is that the government has created national parks without its full ownership of all land inside [11]. Not to be surprising, it is a common phenomenon that can be found in almost every country including Korea.

Out of 22 national parks in Korea, almost all 17 mountain-type national parks have Buddhist temples. These temples have owned a considerable portion of the national parks, called temple forests (called Sachallim). While temple forests account for $7.0 \%$ (about $280 \mathrm{~km}^{2}$ ) of the total area of the national parks [12], the temples have refrained from any kind of developmental use of the land. Consequently, the government has tacitly permitted the temples to charge a private admission fee to park visitors as a means of compensation. However, after the government abolished a government-led user fee in 2007, the conflicts have escalated between park visitors and temples because temples have been still collecting an admission fee. Visitors have been intensely opposed to the private admission fee and have filed lawsuits. They have complained that they do not intend to visit the temples and temple forests but still have to pay the admission fee. Also, the temples have been dissatisfied with development restrictions and continually demanded at least some degree of land development and commercial use of temple forests.

Although it is infeasible, the development of temple forests, however, would result in a loss of ecosystem services. If temple forests are developed, the functions of ecosystem services would decrease at least by the land size of development areas. To make matters worse, park visitors have also criticized that charging the admission fee by the temples is unfair when they mainly intend to visit national parks, not private areas (i.e., temple forests). Lack of public awareness seems to be a primary cause of this problem without knowing that a sizeable part of the national parks is owned by the temples. As a result, due to incomplete information of stakeholders related to ecosystem services and economies of scale in transaction costs, government intervention seems to be inevitable [7,8]. The government wants to resolve this conundrum, and payment for ecosystem services (PES) approach can be adopted as a suitable option to alleviate the conflicts between visitors and temples. Consequently, the purpose of this paper is to assess the economic values of ecosystem services provided by temple forests (i.e., conservation of temple forests) as a compensation mechanism. Ecosystem services provided by temple forests are common property goods that are not traded in the market but have public interest and thus we employed a non-market valuation tool, contingent valuation method (CVM), to estimate the economic value of the ecosystem serviced from temples forests. 
The remainder of the paper is organized as follows: Section 2 reviews previous literature related to national parks in Korea and PES. Section 3 presents the study sites, survey methods, and model analysis. Section 4 presents both descriptive statistics and results of empirical analysis. Finally, policy-related implications and study limitations are discussed in Section 5.

\section{Literature Review}

\subsection{Payments for Ecosystem Services}

The PES approach has been widely used for encouraging conservation, forest regeneration, and wetland management $[13,14]$. PES is defined as "a contractual transaction between a buyer and a seller for an ecosystem service, or land use/management practice likely to secure that service" [15]. Wunder [16] suggested basic principles of the PES: (1) free and voluntary participation in the PES scheme, (2) well-defined ecosystem services, (3) involving at least one provider and buyer, and (4) guaranteed the availability and conservation of the particular ecosystem service. The principles suggested by Wunder have been criticized for being too strict and thus excluding many payment schemes that do not comply with these principles [10]. In particular, the voluntary participation criterion is the main concern because many PES cases are government payment schemes aiming at enhancing social benefits. Rather than applying Wunder's definition that relies on the Coasean conceptualization of markets, Muradian et al. [8] suggested a definition, focusing on the public good characteristic of ecosystem services and the resulting externalities that shall be internalized with the PES. This definition reflects the Pigouvian conceptualization.

According to Engel et al. [7] and Schomers and Matzdorf [10], the main difference between Coasean and Pigouvian concepts of the PES is whether a third party intervenes in the transaction process or not. In the Coasean approach, service buyers are the direct beneficiary of ecosystem services but in the Pigouvian approach, a third party such as the government and government agencies acts on behalf of buyers. Thus, most government payment programs belong to the Pigouvian concept of PES, referring to levying taxes on negative externalities or subsidizing positive externalities [1]. Government payment programs may not be the most efficient option but an advantage of cost-effectiveness due to economies of scale is often preferred to other available options [7].

PES schemes can be an instrument to help maintain the multi-functional role of forests ranging from enhancing biodiversity to improving water quality to mitigating climate change by sequestering and storing carbon [15]. Valuation of ecosystem services can be used to find how much a buyer would be willing to pay and to develop a payment mechanism. More importantly, all stakeholders need to agree on the valuation and payments that are based on opportunity costs associated with foregone revenues from timber or crop sales.

Forests usually provide various ecosystem services such as providing clean water, controlling soil erosion, regulating climate, and enjoying cultural and recreational experiences [17]. Therefore, many countries have implemented PES schemes to get environmental benefits from forest protection. The Swedish government introduced Komet Programme to cover 9\% of Sweden's forest land in 2010. The purpose of the scheme was to raise owners' awareness of the conservation value of the biologically important forest and to encourage them to participate in nature conservation agreements. Owners received fixed-rate payments for nature conservation. In addition, owners received full compensation plus an additional $25 \%$ for habit protection and nature reserves [18]. The Southern Finland Forest Biodiversity Program was initiated in 2002 and extended to across the country in 2008 to protect forest land in Southern Finland, where forests were in commercial use by small-scale non-industrial private owners. Compensation was based on only lost timber income and nature values were used as just eligibility criteria, not affecting the payments [18]. In France, Vittel, the water bottling company, negotiated agreements with the farmers in the catchment area providing the company's water source [19]. The Vittel's PES scheme consisted of one buyer and 26 sellers and covered an area of about 
3600 hectares. Unlike most PES schemes, this agreement embodies the Coasean approach of private consumers' negotiation directly with the suppliers of the services to reach mutually agreeable terms.

The findings of previous literature provide useful guidelines for implementing PES schemes. To find a rational and mutually agreeable range of the PES, Moreno-Sanchez et al. [20] estimated the WTP with heterogeneous groups in income and water-consumption levels in an Andean watershed in Colombia. While recreational-house owners' WTP was $\$ 1.61$ per month more than the current fee, smallholder peasants' WTP was $\$ 0.41$. The authors concluded that users' heterogeneity affected the differences of the WTPs. Bernard et al. [21] estimated the values of ecosystem services provided by the Tapanti National Park in Costa Rica to finance the conservation and sustainable use of the park. The benefits of ecosystem services were about $\$ 2.5$ million per year and the potential payments from the stakeholders amounted to at least $\$ 400,000$ per year. Implementing a PES scheme requires carefully considering different stakeholders' (i.e., beneficiaries and suppliers) benefits and costs associated with ecosystem services. Thus, it is crucial to better understand the economic values of natural resources and the PSE based on the empirical outcomes of the previous studies.

\subsection{Economic Valuation Studies on Protected Areas}

Estimating the economic values of protected areas has received considerable attention. Economic values are referred to as the maximum amount that an individual would pay, and an individual's willingness to pay is a widely approved measure for non-market goods and services [22]. Estimating non-market values can be typically achieved by stated and revealed preference methods. Stated preference methods are a direct method that directly asks survey respondents what they would pay for their preferred alternative. The two main types of stated preference methods are the CVM and choice experiments (CE). The CVM is a method whereby survey respondents are asked to indicate their willingness to pay for a non-market good such as a recreational resource's use values or passive use values including existence value, option value, or bequest value [23]. The CE is a method wherein survey respondents are asked to choose from a set of alternative scenarios that vary in the level of multiple attributes [24]. Indirect measures of non-market values estimate the value of the non-market goods by using consumer's revealed preferences. The travel cost method is a widely used method in this category.

A variety of non-market valuation methods have been used to estimate the values of natural resources such as national parks. Haefele et al. [22] found that the lands, waters, historic sites, and programs of the US National Park System are worth at a minimum $\$ 92$ billion by using the CE. To estimate more specific economic values of natural resources, Neher et al. [25] assessed the recreation use value for the US National Parks at $\$ 28.5$ billion. A body of research has focused on estimating the use or non-use values of individual parks and natural resources (e.g., Turner and Wilmarth [26], Heberling and Templeton [27], Duffield [28], Douglass and Harpman [29]). With regard to valuing natural resources in Korea, Kwak et al. [30] estimated the conservation value of the Woopo Wetland by using the CVM and found that the survey respondents' WTP was between $\$ 2.1$ and $\$ 3.05$ per household per year. It is critical to employ appropriate non-market valuation methods to obtain more precise results.

Prior research examined the effects of social identity on attitudes toward natural resource management and tourism development. Palmer et al., [31] found that the residents' social identity affects their advocacy of tourism development. Especially, they found that cognitive components of social identity had significant direct and indirect effects on advocacy. In the same vein, Ye et al. [32] addressed that residents' social identity plays an important role in explaining their attitudes toward tourism development. Oh and Kim [33] reported that different stakeholders have different WTP for heritage tourism development projects. In the study, service providers were willing to pay significantly more than consumers. Investigating the differences caused by social factors in the economic values of the conservation of natural resources is important and may fill a knowledge gap that previous literature has not focused on much. 
In sum, despite numerous studies that focused on estimating ecosystem services of protected areas and implementing PES schemes, the valuation of ecosystem service from private lands in national parks is rare to the authors' knowledge. As a result, the main objective of this paper is to assess the public willingness to pay for ecosystem services from private lands of national parks (i.e., temple forests) so this information can be used to develop alternative management options in South Korea. More specifically, this study is to investigate the following study questions:

Study Question (1) What are the economic benefits of ecosystem services provided by temple forests?

Study Question (2) Do social factors affect the economic benefits of ecosystem services provided by temple forests?

\section{Methods}

\subsection{National Parks and Temple Forest in Korea}

The national park system of Korea began with the establishment of the Jiri Mountains National Park in 1967. The main purpose of the national park system is to ensure the conservation and sustainable use of natural resources, monuments, and reservations. Currently, a total of 22 national parks, covering $6.7 \%$ of its territory (i.e., a total land and sea area of $6726 \mathrm{~km}^{2}$ and total land of $3973 \mathrm{~km}^{2}$ ), are designated and managed by the Korean government. The national parks consist of 17 mountain national parks, four marine and coastal national parks, and one historic national park [12]. In 2018, over 43 million people had visited the national parks. Most national parks in Korea include Buddhist temples, which are designated as historic or cultural sites and popular tourist attractions. There are 25 temples in 17 mountain national parks and the temples own a sizeable portion of the land and forest in the national parks. Table 1 presents the ownership type of national parks in Korea. A majority of the national park properties are owned by the central government and $7.0 \%$ of total land properties are owned by temples.

Table 1. Property ownership of national parks in Korea.

\begin{tabular}{cccccc}
\hline Type & $\begin{array}{c}\text { Owned by } \\
\text { Central } \\
\text { Government }\end{array}$ & $\begin{array}{c}\text { Owned by } \\
\text { Local } \\
\text { Governments } \\
\text { and Public } \\
\text { Agencies }\end{array}$ & $\begin{array}{c}\text { Owned by } \\
\text { Individuals }\end{array}$ & $\begin{array}{c}\text { Owned by } \\
\text { Temples }\end{array}$ & Total (km²) \\
\hline Total area (land & $4929.5 \mathrm{~km}^{2}$ & $511.1 \mathrm{~km}^{2}$ & $1006.1 \mathrm{~km}^{2}$ & $279.6 \mathrm{~km}^{2}$ & $6726.3 \mathrm{~km}^{2}$ \\
\& sea) & $(73.3 \%)$ & $(7.6 \%)$ & $(14.9 \%)$ & $(4.2 \%)$ & $(100 \%)$ \\
\hline Land area & $2168.6 \mathrm{~km}^{2}$ & $511.1 \mathrm{~km}^{2}$ & $1013.2 \mathrm{~km}^{2}$ & $279.6 \mathrm{~km}^{2}$ & $3972.5 \mathrm{~km}^{2}$ \\
& $(54.6 \%)$ & $(12.9 \%)$ & $(25.5 \%)$ & $(7.0 \%)$ & $(100 \%)$ \\
\hline
\end{tabular}

\subsection{Data Collection}

An online survey was conducted using a panel recruited by an online survey company (Embrain located in Seoul, Korea) in December 2017. In order to select a nationally recruited sample with respect to the 17 geographical areas of residence, a quota sampling strategy was employed in proportion to the population of each metropolitan area. The study population was confined to individuals who have visited at least one of the national parks for the previous five years in order to avoid too many non-responses to national park-related questions. A total of 12,839 invitations were sent out and 2200 individuals were willing to participate in the survey. Among them, 1090 were not qualified based on the criterion of above and the other 158 did not completely fill out the survey. The survey was completed after 1000 individuals completed the questionnaire. 


\subsection{Contingent Valuation Method}

The questionnaire consisted of four different sections. In brief, the questionnaire first asked the respondents about previous visit experience to national parks and temples as well as their awareness of inholdings and perceptions of the importance of the conservation of temples' cultural and religious value. The second part of the questionnaire was the CVM section and the following part asked the respondents' environmentally responsible behaviors in national parks and their trust in the government's environmental policies. Finally, socio-demographic questions were asked in the last part of the questionnaire.

As indicated above, the questionnaire also contained the CVM section to assess individuals' economic value derived from the conservation of temples and temple forests in the national parks. A dichotomous choice format was used that requires respondents to answer YES or NO. Compared to the open-ended format which asks the respondents to reveal the actual the amounts they would be willing to pay, a closed-ended is simpler because respondents are asked to reveal their price taking decision by checking "YES" or "NO" to a CVM question. Nonetheless, this format has been also criticized in that limited information was generated of whether a respondent's true WTP is above the proposed bid amount threshold when she answers YES or her WTP is below the proposed bid amount threshold when she answers NO. Thus, due to its inefficiency nature, the dichotomous choice CVM requires a large sample to increase the precise estimation of the WTP values [34].

As an alternative means, the double bounded dichotomous choice (DB) CVM has been used to improve statistical efficiency with a follow-up dichotomous choice question for a second answer [34]. If a respondent's answer is YES to the first dichotomous choice question for a price of $\$ X$, the respondent is asked if they are willing to pay a higher bid of $\$ X+\$ Y$ in the follow-up question. If a respondent answers NO, the follow-up question is provided to determine whether she is willing to pay a lower bid of $\$ X-\$ Y$. The sequence of questions may increase the complexity of the method because the second question is additionally used. However, the insertion of the second question helps to produce more precise WTP estimates by obtaining more information from each respondent $[35,36]$. To estimate individuals' WTP value, this study made use of this DB-CVM.

The study instrument including the DB-CVM questions was carefully designed with a group of economists and social scientists specializing in outdoor recreation management and was also pretested through Embrain.com to ensure readability and improve validity and reliability. Among different payment options considered, household income tax was selected as a feasible payment vehicle because the government has considered monetary compensation in case a daily entry is abolished. Furthermore, the hypothetical nature of CVM is often a source of criticism and thus, estimated WTP is known to be commonly inflated. This is called hypothetical bias and several different treatments have been used to reduce the difference between hypothetical and real valuations [37]. Among those, cheap talk has been gaining popularity recently as an effective means to reduce the degree of hypothetical bias $[38,39]$. The basic idea of cheap talk is to provide a detailed explanation of the hypothetical bias problem and encourage respondents to make more realistic decisions in CVM questions. As a result, a short script of cheap talk was inserted:

According to a number of studies on the valuation of public goods (such as parks or protected areas), individuals often indicate that they are willing to pay more for the protection of these goods on surveys than what they are actually willing to pay in real life. We believe this is due to the fact that individuals do not really consider how big an impact of the additional spending would actually have on their real-life budget. Individuals are often more likely to be generous and contribute to causes when the scenario is hypothetical than when their money is actually at stake, a problem known as "hypothetical bias". Please be aware of this bias and try to answer the following question in accordance with what you would choose to do in a real scenario.

Then, the exact wording of the first DB-CVM question was as follows:

National parks are protected areas directly managed by the national government to preserve the ecosystems as well as natural and cultural resources that represent Korea. Out of a total of 
22 national parks, 17 famous mountains are designated as national parks. The national parks provide vital ecosystem services such as the provision of ecological habitats, securing water resources, air purification through the absorption of carbon dioxide, water purification, and prevention of soil erosion. The costs of managing and conserving the national parks have been progressively increasing as there is more demand for national park visits derived from growing household income and leisure and health interests.

Almost all of the 17 national parks designated around famous mountains have temples and their forests (called Sachallim), which covers 7.0 percent $\left(280 \mathrm{~km}^{2}\right)$ of the total area of the national parks. Despite the fact that visitors' admission to national parks is free of charge, the temples independently collect an admission fee between $\$ 1000-\$ 5000$ per person) approved by the national government in order to conserve cultural and natural resources in the temples and their forests. The government is considering abolishing the private admission fee due to the resistance of visitors who do not want to visit the temple(s) and the temples, consequently, want to develop the forest land in case they lose the financial source. In this scenario, ecosystem services provided by the national parks are expected to decrease by at least the forest land developed. Therefore, for the conservation of the temple forests, the government plans to compensate the temples with the tax as much of the value as the temple forests. Would you be willing to pay an annual household income tax for the compensation of the temples? Please answer the following question carefully after taking into account that your household income is limited and needs to be spent for a variety of purposes.

If the tax is only used for the compensation of the temples for the value of temples and temple forests, would you be willing to pay additional household income tax of per annum?

For the first DB-CVM question, ten bid values ranging from $\$ 500$ (about US $\$ 0.46$ as of 17 December 2017) and $\$ 30,000$ (\$27.53) were methodically chosen after adjustments based on discussions with the park officials and managers and a couple of pretests of the questionnaire with park visitors. These bid values were randomly assigned to the questionnaires asked to the respondents. For the follow-up DB-CVM question, the bid value presented was doubled, which ranged from $\$ 1000$ (\$0.92) to $\$ 60,000$ (\$55.07), if the response to the first question was "YES." Likewise, a half price of the first bid between $\$ 300$ (\$0.28) and $\$ 15,000$ (\$13.77) was presented if the response to the first one was "NO." For respondents who placed zero (i.e., chose NOs) in both DB-CVM questions, a question was further asked to examine protest behavior (i.e., 'we do not trust the government to implement this properly').

\subsection{Empirical Analysis}

In the case of DB-CVM which provides two bid values $\left(M_{1}: 1\right.$ st bids, $M_{2}: 2$ nd bids) to the respondent $i$ a researcher can observe four different WTP ranges depending on the respondent's answer to the two sequential bid values. Four possible WTP ranges can be expressed as follows.

(1) a respondent says yes for both bid values: $\mathrm{WTP}_{i} \geq M_{2}$

(2) a respondent says yes for 1 st bids but no for 2 nd bids: $M_{1} \leq \mathrm{WTP}_{i} \leq M_{2}$

(3) a respondent says no for 1st bids but yes for 2 nd bids: $M_{2} \leq \mathrm{WTP}_{i}<M_{1}$

(4) a respondent says no for both bid values: $\mathrm{WTP}_{i}<M_{2}$

Taking the structure of WTP intervals into account, this study employs the interval data probit analysis developed by Hanemann et al. [34]. An econometric model based on DB-CVM data formulated by Hanemann et al. [34] consists of two different parts and can be shown by:

$$
\mathrm{WTP}_{k}^{i}=\tau_{k}+\varepsilon_{k}^{i}
$$

where $i=1,2, \ldots, \mathrm{N}$ for each respondent, $k=1,2$ for 1 st and 2 nd bid responses, respectively, $\tau_{k}$ represents the means for the $k$ th responses, and $\varepsilon_{k}^{i}$ denotes random components of $i$ th respondent associated with $k$ th responses, which is assumed to be normally distributed. 
If the assumption that means for each response are equal (i.e., $\tau_{1}=\tau_{2}$ ) holds, Equation (1) can be simplified by removing $k$ expression and rewritten as follows:

$$
\mathrm{WTP}^{i}=\tau+\varepsilon^{i}
$$

Based on Equation (2) the probability (Prob) that respondents will choose for four possible responses can be derived as follows.

(1) a respondent says yes for both bid questions (YES-YES): $\operatorname{Prob}\left(\tau+\varepsilon^{i} \geq M_{2}\right)$

(2) a respondent says yes for 1st bids but no for 2nd bids (YES-NO): $\operatorname{Prob}\left(M_{2}-\tau>\varepsilon^{i} \geq M_{1}-\tau\right)$

(3) a respondent says no for 1st bids but yes for 2nd bids (NO-YES): Prob $\left(M_{1}-\tau>\varepsilon^{i} \geq M_{2}-\tau\right)$

(4) a respondent says no for both bid values (NO-NO): $\operatorname{Prob}\left(\tau+\varepsilon^{i}<M_{2}\right)$

Finally, a likelihood function of the $i$ th respondent $\left(L^{i}\right)$ is expressed as the product of four different probabilities defined above.

$$
\begin{gathered}
L^{i}=\operatorname{Prob}\left(\tau+\varepsilon^{i} \geq M_{2}\right) \times \operatorname{Prob}\left(M_{2}-\tau>\varepsilon^{i} \geq M_{1}-\tau\right) \\
\times \operatorname{Prob}\left(M_{1}-\tau>\varepsilon^{i} \geq M_{2}-\tau\right) \times \operatorname{Prob}\left(\tau+\varepsilon^{i}<M_{2}\right)
\end{gathered}
$$

In the DB-CVM, it is generally assumed that a respondent's true WTP is not different over the sequential payment questions implying the respondent's preference remains unchanged $[34,40]$. This assumption, however, is likely to be violated due to the possibility of preference anomalies [40-42]. Preference anomalies indicate that the initial payments may have an influence on the response of follow-up bid questions. If preference anomalies exist, a researcher may encounter difficulty with eliciting respondent's correct WTP, which in turn leads to inaccurate welfare measures. Therefore, in order to reach conclusive results, it is crucial for research to examine the existence of preference anomalies in the DB-CVM studies.

The representative preference anomalies among others are known as anchoring bias and shift effects [43]. The anchoring bias arises if the respondents anchor their WTP in the initial bid. This case can happen when the respondents believe the 1st bid amounts signify the true value of the environmental goods/services $[41,44]$. In this case, the 2 nd WTP would be adjusted by the sum of a weighted average of the 1st WTP (true WTP) and the 1st bid amounts such as $\mathrm{WTP}_{2}^{i}=(1-\alpha) \mathrm{WTP}_{1}^{i}+\alpha M_{1}$ where $\alpha$ is the respondent's anchored preference in which level of $\alpha$ lies between zero and one. If $\alpha$ is equal to zero (i.e., without anchoring bias) 2nd WTP collapses into the 1st WTP. A higher value of $\alpha$ indicates more anchoring bias in WTP estimates. On the other hand, shift effects take place when the respondents perceive the first bids as the actual costs of government policy. In this case, the 2nd bids may be regarded as additional charges for those who say yes for the 1st bid values while the follow-up question given to the respondents who say no for the 1st question can be considered as an alternative provision for a lower level of environmental quality $[43,45]$. This implies if the respondent's true WTP is based on the 1st bid question, the response to the 2nd bid question can be shown by the respondent's true WTP plus an additional parameter that captures shift effects such as $\mathrm{WTP}_{2}^{i}=\mathrm{WTP}_{1}^{i}+\delta$ where $\delta$ represents a parameter for shift effects with negative sign (If the shift effect exists, the parameter for shift effect will be negative since the provision of the 2 nd bid question is more likely to make the respondents reject 2nd bid amounts [40].

To test for possible existence of anchoring bias and shift effects in the DB-CVM survey, we adopt analytical approaches developed by Whitehead [44], which transforms DB-CVM data into iterative valuation forms in a panel structure where the dependent variable of individual $i=1, \ldots, \mathrm{n}$ at time $k$ $=1, \ldots, \mathrm{k}, \mathrm{WTP}_{i k}$ is defined as upper and lower bounds of WTP. More specifically, the econometric model can be set up as

$$
\mathrm{WTP}_{i k}=\beta_{0}+\delta \text { shift } t_{i}+\text { aanchoring }{ }_{i}+\beta_{s} X_{i k}^{s}+\mu_{k}+\varepsilon_{i t}
$$


where shift $t_{i}$ indicates dummy variable for shift effect and anchoring $g_{i}$ represents anchoring bias which is an interaction variable between shift $t_{i}$ and the first bid value $M_{1}$ (i.e., anchoring $g_{i}=\operatorname{shift}_{i} \times M_{1}$ ). $X_{i k}^{s}$ is the vectors of socio-demographic variables. The term $\beta_{0}, \delta, \alpha$, and $\beta_{s}$ are individual or vectors of coefficients to be estimated. $\mu_{k}$ and $\varepsilon_{i k}$ represent the individual error term for random effect and the random error term, respectively.

\section{Results}

\subsection{Profiles of the Respondents' Perception and Behaviors}

Of the 1000 questionnaires completed, 198 were dropped because of their protest response to the CVM questions and the final data analysis was conducted with the remaining 802. In terms of socio-demographic characteristics of the respondents, there were more males (50.5\%) than females $(49.5 \%)$. The average number of family members was about 2 and the average age of respondents was about 42 . With respect to household monthly income, about half $(52.3 \%)$ of the respondents earned between $\$ 3000$ and $\$ 6000$, followed by more than $\$ 6000$ (23.9\%) and less than $\$ 3000$ (23.8\%). Table 2 summarizes the profiles of the surveyed respondent's perceptions and behaviors with respect to the conservation of the ecosystem services provided by the temples and temple forests in the national parks. Before presenting CVM questions to the respondents, we asked respondents about their perception of the importance of the conservation of temples' cultural and religious value (IHERIT), their environmentally responsible behaviors in national parks (ERB), and their trust in the government's environmental policies (RELGOV).

Table 2. Profiles of the respondents' perceptions and behaviors associated with the conservation of the ecosystem services provided by the national parks.

\begin{tabular}{ccccc}
\hline Variable & Description & Rating Scale & Frequency & Proportion (\%) \\
\hline \multirow{4}{*}{ IHERIT } & Importance on the & 1. strongly disagree & 8 & 1.0 \\
& conservation of & 2. disagree & 26 & 3.2 \\
& temples' cultural & 3. neutral & 143 & 17.8 \\
& and religious & 4. agree & 461 & 57.5 \\
& values & 5. strongly agree & 164 & 20.5 \\
\hline \multirow{2}{*}{ ERB } & Level of & 1. strongly disagree & 1 & 0.1 \\
& environmentally & 2. disagree & 3 & 0.4 \\
& responsible & 3. neutral & 58 & 7.2 \\
& behaviors in & 4. agree & 443 & 55.2 \\
& national parks & 5. strongly agree & 297 & 37.0 \\
\hline \multirow{2}{*}{ RELGOV } & Level of trust in the & 1. very low & 48 & 6.0 \\
& government's & 2. low & 222 & 27.7 \\
& environmental & 3. neutral & 368 & 45.9 \\
& policies & 4. high & 152 & 19.0 \\
\hline
\end{tabular}

Of the 802 responses, a majority of the respondents $(78 \%)$ believed that the conservation of cultural and religious values of temples is important or very important. Respondents' environmentally responsible behaviors in national parks (ERB) were asked using 12 five-point scale items developed by Ryu et al. [46] and the results of exploratory factor analysis (EFA) confirmed a single factor. The variable of ERB was created based on the aggregation of these items. About $92 \%$ of the respondents agreed or strongly agreed that they abided by the environment-friendly behaviors in the national parks when they visited. Finally, respondents' trust in the government's environmental policies was also asked using 12 five-point scale items proposed by Grimmelikhuijsen and Knies [47] and EFA indicated the existence of a single factor. After aggregating these items, a discrete variable of RELGOV was created and about $46 \%$ of the samples said "neutral", followed by a "low" response with $28 \%$. 


\subsection{Descriptions of the Variables}

Table 3 provides the definitions and descriptive statistics of the variables used in the random effects interval data regressions. To secure information on the validity and reliability of the CVM and to generalize study results to the study populations various socio-demographic indicators of individual characteristics were included in the model [36]. Consequently, along with the variables that capture the shift effect (shift) and anchoring bias (anchor) the following explanatory variables were included: IHERIT_dum, ERB, EXP, NVISIT, RELGOV_dum, and AGE. To examine the relative impact of importance on the conservation of temples' cultural and religious values on WTP, we created IHERIT_dum which is a dummy variable equal to one if the level of IHERIT is 4 or greater as described in Table 2. Similarly, the respondent groups who had a high level of their trust in the governments' environmental policies were more likely to accept the bid amount than the other group. Therefore, the RELGOV_dum variable was created to capture the relative difference between the two groups. The variable, EXP represents the dummy variable which is equal to one if the respondents had previously paid admission fees for seeing cultural assets. The variable, NVISIT indicates a total number of trips to the national parks that respondents had visited during the past year and age variable signifies the respondents' age.

Table 3. Definitions and descriptive statistics of variables used in the analysis.

\begin{tabular}{|c|c|c|c|}
\hline Variable & Definition & Mean & Std. Dev. \\
\hline Shift & 1 for shift effects, 0 otherwise & 0.50 & 0.50 \\
\hline Anchor & $\begin{array}{c}\text { anchoring bias (shift } \times \text { first bid } \\
\text { amounts) }\end{array}$ & 3046.45 & 6661.49 \\
\hline IHERIT_dum & 1 if IHERIT $\geq 4$ & 0.78 & 0.41 \\
\hline ERB & $\begin{array}{l}\text { Level of environmentally } \\
\text { responsible behaviors in } \\
\text { national parks }\end{array}$ & 4.29 & 0.62 \\
\hline EXP & $\begin{array}{c}1 \text { if the respondents have paid } \\
\text { the admission fees for cultural } \\
\text { assets }\end{array}$ & 0.71 & 0.45 \\
\hline NVISIT & $\begin{array}{c}\text { No. of trips to national parks in } \\
\text { the last year }\end{array}$ & 1.29 & 1.45 \\
\hline RELGOV_dum & 1 if $\mathrm{RELGOV} \geq 4$ & 0.20 & 0.40 \\
\hline AGE & respondents' age & 41.91 & 12.29 \\
\hline
\end{tabular}

\subsection{Estimation Results}

All model parameters were estimated using the econometric software STATA 15.0 (College Station, TX, USA). The results are presented in Table 4 . Model 1 only includes a constant and a dummy variable that captures shift effects. Model 2 can be regarded as an extended version of model 1 , which incorporates shift effects and anchoring bias simultaneously in the model. Compared to Model 2, Model 3 is an unrestricted model by including additional explanatory variables associated with socio-demographic indicators of the respondents which are assumed to affect the WTP. The presence of random effects in all models was supported by the likelihood-ratio (LR) test of the variance of individual error for random effects (i.e., LR test of $\sigma_{\mu}=0$ in Table 4). 
Table 4. Estimation results of random effects interval regression models.

\begin{tabular}{|c|c|c|c|c|c|c|}
\hline \multirow{2}{*}{$\begin{array}{c}\text { Model } \\
\text { Variable }\end{array}$} & \multicolumn{2}{|c|}{ Model 1} & \multicolumn{2}{|c|}{ Model 2} & \multicolumn{2}{|c|}{ Model 3} \\
\hline & Coefficient & Std. Err. & Coefficient & Std. Err. & Coefficient & Std. Err. \\
\hline constant & $8475.055^{*}$ & 69.610 & $7842.64 *$ & 59.558 & $6035.995 *$ & 319.974 \\
\hline shift & $-279.266^{*}$ & 64.812 & $-275.797 *$ & 59.079 & $-255.527^{*}$ & 45.557 \\
\hline anchor & & & $0.037^{*}$ & 0.009 & $0.055 *$ & 0.008 \\
\hline \multicolumn{2}{|c|}{ IHERIT_dum } & & & & $1228.182 *$ & 112.082 \\
\hline \multicolumn{2}{|c|}{ ERB } & & & & -59.318 & 84.175 \\
\hline \multicolumn{2}{|l|}{ EXP } & & & & 996.771 * & 76.201 \\
\hline \multicolumn{2}{|l|}{ NVISIT } & & & & $952.663 *$ & 17.525 \\
\hline \multicolumn{2}{|c|}{ RELGOV_dum } & & & & $1616.680 *$ & 81.149 \\
\hline \multicolumn{2}{|l|}{ AGE } & & & & $-38.068 *$ & 2.833 \\
\hline LR test of $\sigma_{\mu}=0$ & \multicolumn{2}{|c|}{$\chi^{2}(1)=853.98 *$} & \multicolumn{2}{|c|}{$\chi^{2}(1)=785.36^{*}$} & \multicolumn{2}{|c|}{$\chi^{2}(1)=837.07 *$} \\
\hline $\mathrm{N}$ & \multicolumn{2}{|c|}{1604} & \multicolumn{2}{|c|}{1604} & \multicolumn{2}{|c|}{1604} \\
\hline LL & \multicolumn{2}{|c|}{-1835.24} & \multicolumn{2}{|c|}{-1820.2} & \multicolumn{2}{|c|}{-1773.43} \\
\hline Mean WTPa & \multicolumn{2}{|c|}{5908.2} & \multicolumn{2}{|c|}{6075.1} & \multicolumn{2}{|c|}{7708.9} \\
\hline $95 \%$ CI of WTPb & \multicolumn{2}{|c|}{$5280.0-6536.5$} & \multicolumn{2}{|c|}{$5451.5-6698.6$} & \multicolumn{2}{|c|}{$7017.5-8400.3$} \\
\hline
\end{tabular}

${ }^{*}$ Statistically significant at $1 \%$ level; ${ }^{a}$ the unit of mean WTP is KRW/household/year; ${ }^{b} 95 \%$ of confidence interval of WTP is obtained based on delta methods.

In all three models, the shift variable is negative and statistically significant, which implies a descending shift in the WTP. According to Albernini et al. [45], Whitehead [44], and Gelo and Koch [43], the negative sign of shift effects is related to the nay-saying effect while the opposite sign is associated with a yea-saying effect. Our result is in line with the findings reported in those studies. With respect to anchoring bias, the sign of anchor variable is positive and statistically significant at $1 \%$ level as well as the magnitude of the parameter lies between zero and one in all three models, which is coincident with the standard assumption of anchoring bias discussed in the literature. This result indicates that the 1st bid amounts may have an influence on the response to the 2nd bid question.

Turning to the impact of socio-demographic factors on WTP in Model3, most of the variables except ERB are statistically significant and generally follow our expected signs. For example, the positive coefficients of IHERIT_dum and RELGOV_dum variables indicate that individuals who placed more importance on the conservation of temples' cultural and religious values and who had a higher level of their trust in the governments' environmental policies were more likely to pay proposed income tax amounts. Similarly, the respondents who have paid the admission fee for cultural assets in the national parks were more willing to pay taxes to prevent the deterioration of the ecosystem services provided by temples and temple forests in the national parks. The positive sign of NVISIT implies that the respondents who had more trips to the national parks were likely to pay taxes whereas older respondents were less likely to respond "YES" to the CVM questions.

To compare model fits between the models, we applied the LR tests since each model is a nested version of the other models. With respect to model performance between Model 1 and Model 2, the log-likelihood value of Model 2 was significantly improved and Model 2 is preferred over Model 1 based on the LR test. A comparison between Model 2 and Model 3 indicates that adding six more variables resulted in a significant improvement in model fit and the LR test supported the use of Model 3.

Based on the parameter estimates in Table 5, the mean WTP was calculated using the mean value of each variable which is statistically significant. The mean WTP per household per year was estimated to be $\$ 5908$ (\$5.42), respectively. These estimated mean WTPs can be interpreted as households' net benefits accrued from the conservation of temple forests. 
Table 5. The comparison of mean WTPs between two different groups based on social variables.

\begin{tabular}{|c|c|c|c|c|c|c|c|}
\hline Variable & Group & Definition & $\mathbf{N}$ & $\begin{array}{c}\text { Mean } \\
\text { WTP }(\mathbf{W})\end{array}$ & $\begin{array}{l}\text { Std. } \\
\text { Dev. }\end{array}$ & $t$-test ${ }^{a}$ & $p$-Value \\
\hline \multirow{2}{*}{ IHERIT } & $\begin{array}{l}\text { Low } \\
\text { IHERIT }\end{array}$ & $\begin{array}{l}\text { Level of IHERIT } \\
<4\end{array}$ & 177 & 6635.44 & 1644.07 & \multirow[t]{2}{*}{-9.399} & \multirow[t]{2}{*}{0.000} \\
\hline & $\begin{array}{l}\text { High } \\
\text { IHERIT }\end{array}$ & $\begin{array}{l}\text { Level of IHERIT } \\
\quad \geq 4\end{array}$ & 625 & 7962.82 & 1662.76 & & \\
\hline \multirow{2}{*}{ RELGOV } & $\begin{array}{c}\text { Low } \\
\text { RELGOV }\end{array}$ & $\begin{array}{c}\text { Level of } \\
\text { RELGOV }<4\end{array}$ & 638 & 7280.59 & 1498.98 & \multirow[t]{2}{*}{-13.852} & \multirow[t]{2}{*}{0.000} \\
\hline & $\begin{array}{c}\text { High } \\
\text { RERLGOV }\end{array}$ & $\begin{array}{c}\text { Level of } \\
\text { RELGOV } \geq 4\end{array}$ & 164 & 9184.27 & 1819.92 & & \\
\hline
\end{tabular}

${ }^{a}$ : The null hypothesis of the $t$-test is the mean difference of WTP between two groups is equal to 0 using mean WTP, standard deviation, and number of observations for each group.

We also examined the difference of WTP distinguished by social variables such as IHERIT and RELGOV variables. For this purpose, we recalculated the WTPs and segmented respondents into two groups based on their response to IHERIT and RELGOV variables (i.e., high versus low groups in Table 5). We then compared the WTPs between these two groups and tested whether the mean WTPs are statistically different between the two groups using a standard hypothesis test. The results are given in Table 5. The results indicate that the null hypothesis of WTP equality was rejected at the $1 \%$ level, suggesting that the high IHERIT group was willing to pay considerably more than the low IHERIT group. The difference is about 1327.4. Similarly, a substantial difference of WTPs (about \#1903.7) between the low RELGOV and high RELGOV groups was supported by the statistical test.

Finally, we calculated the total social benefits of ecosystem services provided by temples and temple forests in the national parks using the mean WTP in Model 3 since Model 3 outperforms the other two models. According to the 2017 Basic Statistics of Korean National Parks provided by Korea National Park Service [48], there were 44,131,000 individuals who had visited 22 national parks and $30,952,000$ visitors when taking only into account 17 national parks where 25 temples and temple forests are located within the national parks in 2017. In order to convert these figures into the number of households, we applied an average family number (2.476) obtained from Statistics Korea in 2017. Using these figures, we calculated the total number of households who had visited national parks in 2017. Table 6 presents the estimated total social benefits of visitors. The total social benefits were calculated to be about 96.4 billion ( $\$ 88.5$ million) and $\$ 137.4$ billion ( $\$ 126.1$ million) and per year based on the number of households visiting 17 national parks and 22 national parks, respectively.

Table 6. Total social benefits of ecosystem services provided by temples and temple forests.

\begin{tabular}{ccccc}
\hline $\begin{array}{c}\text { Total Number of } \\
\text { National Parks }\end{array}$ & $\begin{array}{c}\text { Total Number of } \\
\text { Households } \\
\text { Visited }\end{array}$ & $\begin{array}{c}\text { Mean WTP } \\
\text { (W/year/household) }\end{array}$ & $\begin{array}{c}\text { Total Benefits (W } \\
\text { Billion/year) }\end{array}$ & $\begin{array}{c}\text { 95\% CI of Total } \\
\text { Benefits (W } \\
\text { Billion/year) }\end{array}$ \\
\hline 22 national parks & $17,820,834$ & 7708.9 & 137.4 & $125.1-149.7$ \\
\hline 17 national parks & $12,498,934$ & 7708.9 & 96.4 & $87.7-105.0$ \\
\hline
\end{tabular}

\section{Discussion}

This paper aimed to assess the economic values of ecosystem services provided by temple forests in Korea to help the government take into consideration of the PES scheme as a means of resolving conflicts. A DB-CVM survey was conducted with a sample of individuals who had visited national parks. Using the analytical framework of random effects interval data regressions, we attempted to explore the issues of the potential existence of preference anomalies, namely anchoring bias and shift effects which are commonly addressed in DB-CVM studies. The presence of preference anomalies was detected in our DB-CVM data, suggesting that precautious modeling approaches are required in order 
to elicit precise WTP in the DB-CVM analysis. The results also showed that the economic benefits of the conservation of temple forests were estimated to be substantial, ranging from $\$ 5980$ (\$5.42) to \$7709 (\$7.08) per year depending on the regression models used. Finally, this study examined and confirmed the effects of various social factors such as trust in the government's environmental policies and importance on the conservation of temples' cultural and religious values on the WTPs.

Based on the empirical findings, the following policy implications can be inferred, which can be helpful for policymakers in designing a suitable PES scheme to alleviate the conflicts between the stakeholders. First, the economic values of ecosystem services provided by temple forests can be linked with the institution of the PES scheme. As indicated above, the total social benefits amounted to between $\$ 96.4$ billion ( $\$ 88.5$ million) and $\$ 137.4$ billion (\$126.1 million) per year depending on the number of visitors used. The admission fee varied in the temples and temple forests, ranging from 1000 to $\$ 5000$ per visitor. According to the Cultural Heritage Administration of Korea [49], the revenues from the total admission fee collected by the temples were estimated to be around 26.8 billion ( $\$ 24.6$ million).

\section{Conclusions}

Our results are a well-matched example with the concept of PES. Because the suppliers (i.e., temples who own a sizeable portion of the land in the national parks) provide valuable ecosystem services, even if they do not intend to do so, to the beneficiary (i.e., current and future visitors), they need to compensate the suppliers for the services competitively. As the total social benefits that we calculated well exceeded the revenues of the temples, a PES scheme through the government initiated user fee after abolishing a private admission fee can be a viable alternative. Furthermore, we confined the beneficiary only to current park visitors in national parks. However, when the scope of the beneficiary is further expanded to the national population beyond park visitors, the total social benefits amounted to $\$ 1641.5$ billion ( $\$ 150.7$ million) based on the number of Korean households, 21,294,009 [48]. From the perspective of four ecosystem services (i.e., provisioning, regulating, cultural and supporting services) that temple forests provide to humans [2], it could be reasonable to include the entire population of Korea as the beneficiary. When exclusion costs are high and user fees typically cause visitors' protests, a Pigouvian solution such as state taxes and direct subsidies can be a more favoring PES scheme to settle down the conflicts between the stakeholders [1].

Second, significant differences of the WTPs between the segmented groups need to be considered in the decision-making process of instituting a PES scheme. In particular, individuals who perceive higher importance of the temples' cultural and heritage value and those who place a higher level of public trust in the government's policies tend to view a PES scheme of government invention more favorably. Social worlds and social theories may help explain why there are WTP differences. According to the theories, individuals tend to divide themselves into distinctive groups for collective thoughts and actions such as in-group and out-group based on certain criteria such as nationality, gender, and age as well as common belief and action system, shared perspectives and subcultures [32,50,51]. In-group and out-group classification indicates that when one's affinity for the in-group increases, so does the evaluation toward the in-group [33,52]. Thus, the in-group who has a close tie with Buddhism perceives temple forests more importantly and this subsequently leads to their positive appraisal for government intervention through higher WTPs of a PES scheme.

For effective policy and management decisions related to a PES scheme, adequate efforts are required to account for different viewpoints from the segmentation analysis. For example, individuals with a high level of trust in the government's environmental policies are willing to pay significantly more (about $\$ 1900$ or $\$ 1.74$ ) than the counterpart but only $20 \%$ of the respondents had a high or very high level of trust in the government's environmental policies. This probably results from people's distress and distrust owing to the non-transparent and inconsistent policy decision-making process and implementation of the government's environmental policies recurrently. Therefore, the government should make an effort to build public trust in the government's policies by actively engaging stakeholders 
in the decision-making process, acting as a mediator to draw consensus among them, and instituting policies on a coherent basis [47].

Several study limitations and future research directions are worth noting here. First, the study sample was park visitors for the data of this study due to their familiarity with the admission fee. A PES scheme through subsides will rely on taxes from the general public. Thus, future studies will be required with a sample of general people to assure the generalizability of the study findings. Second, temples are one of the various inholders. It is known that about one-quarter of the total area of the national parks is owned by individual owners [12]. While they were not included in this study, future studies will be beneficial with all of the inholders for effective implementation of a PES scheme. Third, the economic values in this study were estimated as the scale of compensation for the temples and are likely to be assessed in a conservative manner. Subsequently, the results of this study are likely to be a lower end of the values and are different from the studies that intended to assess the total economic values of national parks.

With a growing interest in securing ecosystem services through a PES approach, estimating economic benefits of the conservation of inholdings in public protected areas will be a valuable piece of information as an important policy decision-making tool. It will be ultimately the government's decision to choose a PES scheme between a new public user fee and direct government support through subsidies. However, any type of government interventions should be fully consulted with stakeholders including temples, current and potential visitors, and non-visitors to maximize social net benefits.

Author Contributions: Data collection: C.-O.O.; Conceptualization: C.-O.O., and H.N.K.; Data analysis: H.N.K., C.-O.O.; Writing-Original Draft Preparation: C.-O.O., S.L., and H.N.K.

Funding: This study was carried out under the project titled "Marine Ecosystem-Based Analysis and Decision-Making Support System Development for Marine Spatial Planning" by the Ministry of Oceans and Fisheries (grant number 20170325). The usual disclaimer applies.

Acknowledgments: It is gratefully acknowledged that the data used in this paper were originally collected as part of a research project supported by the National Institute of Ecology, Republic of Korea. We appreciate Woo-young Joo and Haeyong Jeong, who provided their invaluable contributions during the data collection phase. This study was also financially supported by the research project (GP2019-10) of the Korea Environment Institute (KEI).

Conflicts of Interest: The authors declare no conflict of interest.

\section{References}

1. Vatn, A. An institutional analysis of payment for environmental services. Ecol. Econ. 2010, 69, 1245-1252. [CrossRef]

2. Millennium Ecosystem Assessment. Ecosystems and Human Well-Being: Synthesis; Island Press: Washington, DC, USA, 2005.

3. The World Bank. Five Forest Figures for the International Days of Forests. World Bank Data Blog. 2016. Available online: https://blogs.worldbank.org/opendata/five-forest-figures-international-day-forests (accessed on 12 July 2019).

4. Tietenberg, T. Environmental Economics and Policy, 4th ed.; Pearson Addison Wesley: Boston, MA, USA, 2004.

5. Derissen, S.; Latacz-Lohmann, U. What are PES? A review of definitions and an extension. Ecosyst. Serv. 2013, 6, 12-15. [CrossRef]

6. Jack, B.K.; Kousky, C.; Sims, K.R.E. Designing Payments for Ecosystem Services: Lessons from Previous Experience with Incentive-Based Mechanisms. Proc. Natl. Acad. Sci. USA 2008, 105, 9465-9470. [CrossRef] [PubMed]

7. Engel, S.; Pagiola, S.; Wunder, S. Designing payments for environmental services in theory and practice: An overview of the issues. Ecol. Econ. 2008, 65, 663-674. [CrossRef]

8. Muradian, R.; Corbera, E.; Pascual, U.; Kosoy, N.; May, P. Reconciling theory and practice: An alternative conceptual framework for understanding payments for environmental services. Ecol. Econ. 2010, 69, 1202-1208. [CrossRef] 
9. Pattanayak, S.; Wunder, S.; Ferraro, P.J. Show me the money: Do payments supply environmental services in developing countries? Rev. Environ. Econ. Policy 2010, 4, 254-274. [CrossRef]

10. Schomers, S.; Matzdorf, B. Payments for ecosystem services: A review and comparison of developing and industrialized countries. Ecosyst. Serv. 2013, 6, 16-30. [CrossRef]

11. Tanner, R. Inholdings within wilderness. Int. J. Wilder. 2002, 8, 9-14.

12. KNPS. The 2019 Basic Statistics of Korean National Parks; Korea National Park Service: Wonju, Korea, 2019.

13. Lipper, L.; Sakuyama, T.; Stringer, R.; Zilberman, D. Payment for Environmental Services in Agricultural Landscapes: Economic Policies and Poverty Reduction in Developing Countries; Springer: New York, NY, USA, 2009.

14. UNEP; Forest Trends; The Katoomba Group. Payments for Ecosystem Services Getting Started: A Primer; UNEP/Forest Trends/The Katoomba Group: Washington, DC, USA, 2008.

15. United Nations Economic Commission for Europe. Convention on the Protection and Use of Transboundary Watercourses and International Lakes: Recommendations on Payments for Ecosystem Service in Integrated Water Resources Management; UN: New York, NY, USA, 2007.

16. Wunder, S. Payment for Environmental Services: Some Nuts and Bolts; CIFOR Occasional Paper No. 42; Center for International Forestry Research: Bogor, Indonesia, 2005.

17. Alix-Garcia, J.; Wolff, H. Payment for ecosystem services from forests. Annu. Rev. Resour. Econ. 2014, 6, 361-380. [CrossRef]

18. Viszlai, I.; Barredo, J.I.; San-Miguel-Ayanz, J. Payments for Forest Ecosystem Services: SWOT Analysis and Possibilities for Implementation; EUR28128 EN: Rome, Italy, 2016. [CrossRef]

19. Wunder, S.; Wertz-Kanounnikoff, S. Payments for ecosystem services: A new way of conserving biodiversity in forests. J. Sustain. For. 2009, 28, 576-596. [CrossRef]

20. Moreno-Sanchez, R.P.; Maldonado, J.H.; Wunder, S.; Borda-Almanza, C. Heterogeneous users and willingness to pay in an ongoing payment for watershed protection initiative in the Colombian Andes. Ecol. Econ. 2012, 75, 126-134. [CrossRef]

21. Bernard, F.; deGroot, R.S.; Campos, J.J. Valuation of tropical forest services and mechanism to finance their conservation and sustainable use: A case study of Tapanti National Park, Costa Rica. For. Policy Econ. 2009, 11, 174-183. [CrossRef]

22. Haefele, M.; Loomis, J.B.; Bilmes, L. Total Economic Valuation of the National Park Service Lands and Programs: Results of a Survey of the American Public; HKS Working Paper No. 16-024; Harvard University: Cambridge, MA, USA, 2016; Available online: https://ssrn.com/abstract=2821124 (accessed on 6 May 2019). [CrossRef]

23. Mitchell, R.C.; Carson, R.T. Using Surveys to Value Public Goods: The Contingent Valuation Method; Resources for the Future: Washington, DC, USA, 1989.

24. Bennett, J.; Blamey, R. The Choice Modelling Approach to Environmental Valuation; Edward Elgar: Cheltenham, UK, 2001.

25. Neher, C.; Duffield, J.; Patterson, D. Valuation of national parks system visitation: The efficient data models, meta-analysis, and secondary visitor survey data. Environ. Manag. 2013, 52, 683-698. [CrossRef] [PubMed]

26. Turner, R.W.; Willmarth, B. Valuation of Cultural and Natural Resources in North Cascades National Park: Results from a Tournament-Style Contingent Choice Survey; Economics Faculty Working Papers; Department of Economics, Colgate University: Hamilton, NY, USA, 2014.

27. Heberling, M.T.; Templeton, J.J. Estimating the economic value of national parks with count data models using on-site, secondary data: The cast of the Great Sand Dunes National Park and Preserve. Environ. Manag. 2009, 43, 619-627. [CrossRef]

28. Duffield, J.W. Economic Values of National Park System Resources Within the Colorado River Watershed; Report prepared for the National Park Service Environmental Quality Division; Cooperative Agreement H1200040002; Task J2380050112; National Park Service: Washington, DC, USA, 2006.

29. Douglas, A.J.; Harpman, D.A. Lake Powell management alternatives and values: CVM estimates of recreation benefits. Water Int. 2004, 29, 375-383. [CrossRef]

30. Kwak, S.J.; Yoo, S.H.; Lee, C.K. Valuation of the Woopo Wetland in Korea: A contingent valuation study. Environ. Dev. Econ. 2007, 12, 323-328. [CrossRef]

31. Palmer, A.; Koenig-Lewis, N.; Medi Jones, L.E. The effects of residents' social and involvement on their advocacy of incoming tourism. Tour. Manag. 2013, 38, 142-151. [CrossRef] 
32. Ye, B.H.; Zhang, H.Q.; Shen, J.H.; Goh, C. Does social affect residents' attitude toward tourism development? An evidence from the relaxation of the individual visit scheme. Int. J. Contemp. Hosp. Manag. 2014, 26, 907-929.

33. Oh, C.; Kim, H. Stakeholder differences in economic benefits of heritage tourism development. Tour. Econ. 2016, 22, 665-670. [CrossRef]

34. Hanemann, W.; Loomis, J.; Kanninen, B. Statistical efficiency of double-bounded dichotomous choice contingent valuation. Am. J. Agric. Econ. 1991, 73, 1255-1263. [CrossRef]

35. Cameron, T.A.; Huppert, D.D. Referendum contingent valuation estimates: Sensitivity to the assignment of offered values. J. Am. Stat. Assoc. 1991, 86, 910-918. [CrossRef]

36. Haab, T.; McConnell, K.E. Valuing Environmental and Natural Resources: The Econometrics of Non-Market Valuation; Edward Elgar Publishing: Cheltenham, UK, 2002.

37. Grafton, R.Q.; Adamowicz, W.L.; Dupont, D.; Nelson, H.; Hill, R.J.; Renzetti, S. The Economics of the Environment and Natural Resources; Blackwell Publishing: Hoboken, NJ, USA, 2004.

38. Aadland, D.; Caplan, A. Household Valuation of Curbside Recycling. J. Environ. Plan. Manag. 1999, 42, 781-799. [CrossRef]

39. Cummings, R.G.; Taylor, L.O. Unbiased Value Estimates for Environmental Goods: A Cheap Talk Design for the Contingent Valuation Method. Am. Econ. Rev. 1999, 89, 649-665. [CrossRef]

40. Choi, I.C.; Kim, H.N.; Shin, H.J.; Tenhunen, J.; Nguyen, T.T. Willingness to pay for a highland agricultural restriction policy to improve water quality in South Korea: Correcting Anomalous Preference in contingent valuation method. Water 2016, 8, 547. [CrossRef]

41. Herridges, J.A.; Shogren, J.F. Starting point bias in dichotomous choice valuation with follow-up question. J. Environ. Econ. Manag. 1996, 30, 112-131. [CrossRef]

42. Flachaire, E.; Hollard, G. Controlling starting-point bias in double-bounded contingent valuation surveys. Land Econ. 2006, 82, 103-111. [CrossRef]

43. Gelo, D.; Koch, S.F. Contingent valuation of community forestry programs in Ethiopia: Controlling for preference anomalies in double-bounded CVM. Ecol. Econ. 2015, 114, 79-89. [CrossRef]

44. Whitehead, J.C. Incentive incompatibility and starting point-bias in iterative valuation question. Land Econ. 2002, 78, 285-297. [CrossRef]

45. Alberini, A.; Kanninen, B.; Carson, R. Modeling response incentive effect in dichotomous contingent valuation. Land Econ. 1997, 73, 309-324. [CrossRef]

46. Ryu, J.; Jang, W.S.; Kim, J.; Choi, J.D.; Engel, B.A.; Yang, J.E.; Lim, K.J. Development of a Watershed-Scale Long-Term Hydrologic Impact Assessment Model with the Asymptotic Curve Number Regression Equation. Water 2016, 8, 153. [CrossRef]

47. Grimmelikhuijsen, S.; Knies, E. Validating a scale for citizen trust in government organizations. Int. Rev. Adm. Sci. 2017, 83, 583-601. [CrossRef]

48. Statistics Korea. Available online: http://kostat.go.kr/portal/eng/ (accessed on 5 September 2019).

49. Cultural Heritage Administration of Korea. Available online: http://english.cha.go.kr (accessed on 5 September 2019).

50. El-Aswad, E.-S. Social worlds. Encycl. Soc. Med. Pol. 2014, 1, 1148-1151.

51. Unruh, D.R. The nature of social worlds. Pac. Sociol. Rev. 1980, 23, 271-296. [CrossRef]

52. Turner, J.C. A self-categorization theory. In Rediscovering the Social Group: A Self-Categorization Theory; Turner, J.C., Hogg, M.A., Oakes, P.J., Reicher, S.D., Wetherell, M.S., Eds.; Basil Blackwell: Oxford, UK, 1987.

(C) 2019 by the authors. Licensee MDPI, Basel, Switzerland. This article is an open access article distributed under the terms and conditions of the Creative Commons Attribution (CC BY) license (http://creativecommons.org/licenses/by/4.0/). 